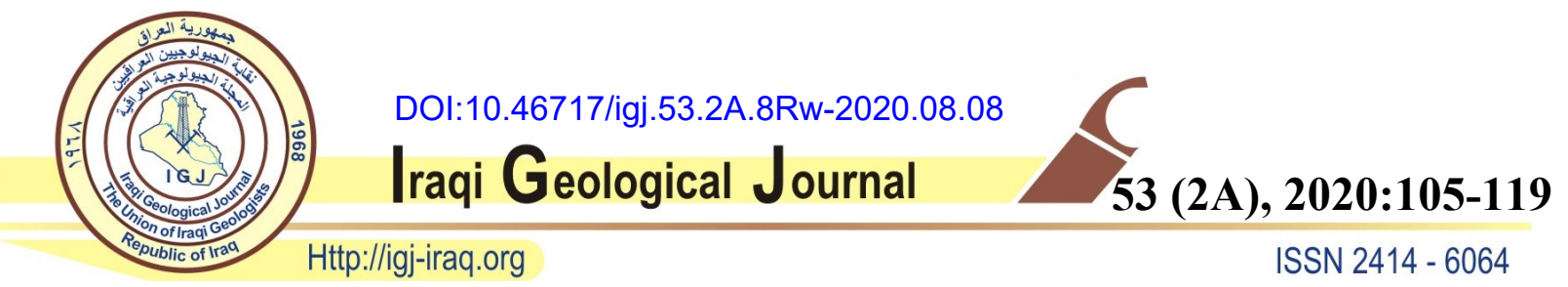

\title{
EFFECT OF TECTONIC SETTING ON DISTRIBUTION OF PELAGIC SEDIMENT UNIT (SHIRANISH FORMATION) IN ZAGROS FORELAND BASIN, IRAQI SEGMENT
}

\author{
${ }^{1}$ Rabeea Kh. Znad ${ }^{*}$, ${ }^{1}$ Saddam E. Al-Khatony and ${ }^{1}$ Mahmood A. H. Al-Sumaidaie \\ ${ }^{1}$ Department of Geology, College of Science, University of Mosul, Mosul, Iraq \\ *E-mail: rabeeazinad@unmosul.edu.iq \\ Received: 23 February 2020; accepted: 21 May 2020
}

\begin{abstract}
Shiranish Formation represents the uppermost Cretaceous pelagic sediment unit of the Iraqi segment within the western Zagros fold and the thrust belt. The occurrence of the formation governed by the northern edge of the Neabo-Arabian plate's tectonic activity and the distribution has now been interpreted according to the modern tectonic concept of the foreland basin system. Field data and Isopach map have shown that two main basins existed on both sides of the Forebulge (Qamchuqa Formation). Currently, the first one has extended north west-southeast within the foredeep depozone, while the second one, which represents the Backbulge Depozone. The influence of the tectonic rise of the Forebulge Depozone leads to a non-existing pelagic sediments unit of the Shiranish Formation in the area restricted from northwest Amadiya town (the south limb of Mateen Anticline) towards southeast areas (Gara Anticline), thereafter to Aqra areas. Thus, the absence of the formation in the Shikhan area (e.g.) refers to inhomogeneity on the backbulge basin causing exposed or submerged areas during the age of upper Cretaceous.
\end{abstract}

Keywords: Foreland basin; Forebulge; Backbulge; Isopach map

\section{INTRODUCTION}

The northern and eastern margins of the Nubian-Arabian plate were affected by episodically compressional stresses in the pre collisional orogeny stage (during Cretaceous). Particularly, the stresses increased in the Late Cretaceous. These stresses may attribute to the subduction of the oceanic crust plate and cause the accumulation of accretionary prism of Qulqula Radiolarite serpentinite mélange slices (Ali et al., 2019; Aziz et al., 2011a). However, according to (Ibrahim, 2009; Agard et al., 2011), ophiolite abducted on the stated NE margin of the continental Arabian plate. The continental crust, however, flexed due to the overload under the influence of the accretionary prism assemblages. Consequently, the flexural foreland-Zagros basin system in the Iraqi segment undergoes an under-filled stage. Therefore, 
the simultaneously trinity sedimentary units deposited in the foredeep depozone (Znad, 2013). According to (Sinlcair, 1997a), the lower unit of the trinity represents the sediments of the shallow seas (the carbonate platform) and the middle unit represents the open sea sediments rich in the pelagic and the upper unit flysch sediments. The Shiranish Formation crops out in many localities on northern Iraq and possessing various stratified relationship laterally and vertically with many formations, both older and younger. Previous studies have diagnosed the sedimentation environment of the formation in a deep open marine- pelagic. (Jassim and Buday, 2006; Buday,1980). The formation, however, has a special interest in many oil companies. This is because the formation provides a good seal for significant hydrocarbon accumulations in underlying Hartha limestone Formation as in the Fallujah and Majnoon fields in the middle and southern Iraq, however, it represents hydrocarbon reservoir in AinZala and Taqtaq in northern part of Iraq (Alsharhan and Narin, 2003). The aim of the study is to explain the tectonic effect of the Zagros foreland basin-Iraqi segment on the distribution of the Shiranish Formation and the development of a tectonic model according to the modern concepts of the basin system. The aim of the study is also to draw up an Isopach map for formation in the northern Iraq.

\section{MATERIALS AND METHODS}

The research method was divided into field and office work. Fieldwork included the followup of the formation in most of the areas of its exposure in northern Iraq (Fig. 1) (in all accessible areas), in each site, was recorded geographical coordinates a, note field observations and measurement of true thickness and the relationship of formation laterally and vertically with the formations in that location. The office work included arranging, scheduling, and mapping of the information of the true thickness and geographic coordinates of each site, for the purpose of inclusion in the server program and was drawn map of the true thickness (Isopach map) to distribution in northern Iraq. The AutoCAD program is used to draw a stereoscopic shape of a depositional basin.

\section{GEOLOGIC AND TECTONIC SETTING}

\section{Foreland Basin Concept}

Foreland basin is known as longitudinal depression on the continental lithosphere formed between the orogenic belt and stable craton (Fig. 2). initiated as a result of flexural subsidence of continental crust in the response of protracted tectonic thrust sheets loads through plates convergent. (De Celles, 2012; Naylor and Sinclair, 2008; Allen and Allen, 2005; Catuneanu, 2004; Beaumont, 1981). 


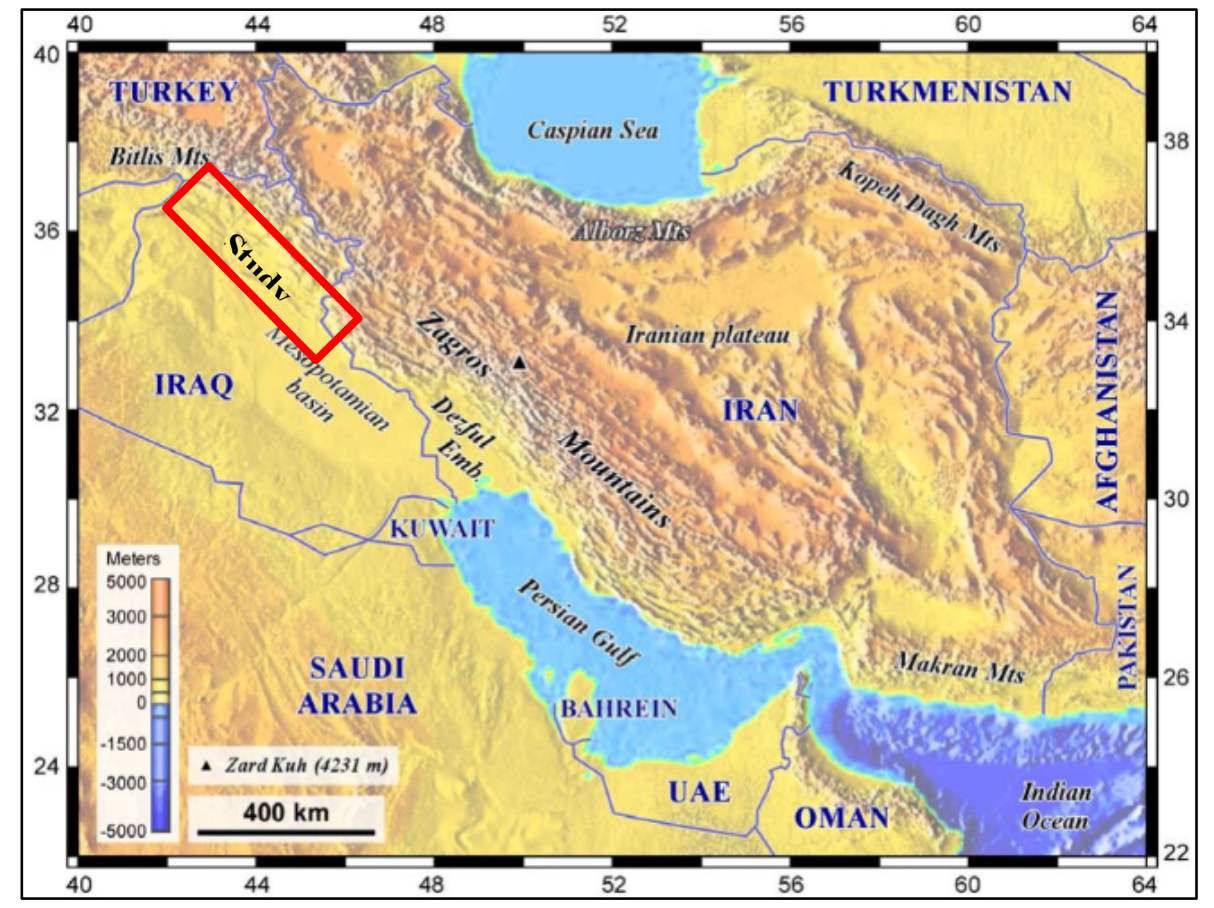

Fig. 1. Geographic and topographic map of the Zagros fold (Homke, 2007)

Foreland basins are complicated geometrical structures containing distinct parts that are incorporated to varying degrees (De Celles and Giles, 1996), who adopted the definition of the foreland basin system. As following:

I) They reflect longitudinal basins suitable for the deposition of sediments, forming on the continental crust between the craton and orogenic belts in response to the geodynamic processes as Arabian Plate result of the subduction zone and building of orogenic belts.

II) The typical Foreland basin system consists of four central deposition areas. (wedge-top, foredeep, forebulge and backbulge). The dimensions and intensity of the bending wave resulting in the four-foreland basin system depozones depend on the geometry and density of the tectonic load, rheological properties of the lithosphere, size and density of the basin-filling sediment, the amount of orogenic wedge erosion and forebulge. These depozones not fixed temporally or spatially, and overlap between them to form a complex pattern of sediment distribution, and diachronous orogeny along the strike leads to a variation in the shift of the general shape of the foreland basin towards the craton. Also, the forebulge and the backbulge depozones may be poorly developed or missing in certain foreland basin systems. The depozone wedge-top contains sediment that hides the effective frontal portion of the thrust zone. While wedge-top deposits are typified by textural and compositional immaturity, growth structures are its defining feature. Most of the deposits in the foredeep basin were derived from the thrust band belts, with secondary participation from the forebulge and craton. As for the forebulge, 
this depozone occupies the area of flexural uplift along the craton side in front of the foredeep depozone. The backbulge depozone It includes the sediments that exist between the area of the forebulge and the craton, most of the sediments come from the side of the forebulge with a secondary contribution from the craton, and in the submarine environments, a carbonated platform may develop in which the stratification units are generally thinner than those in foredeep depozone.

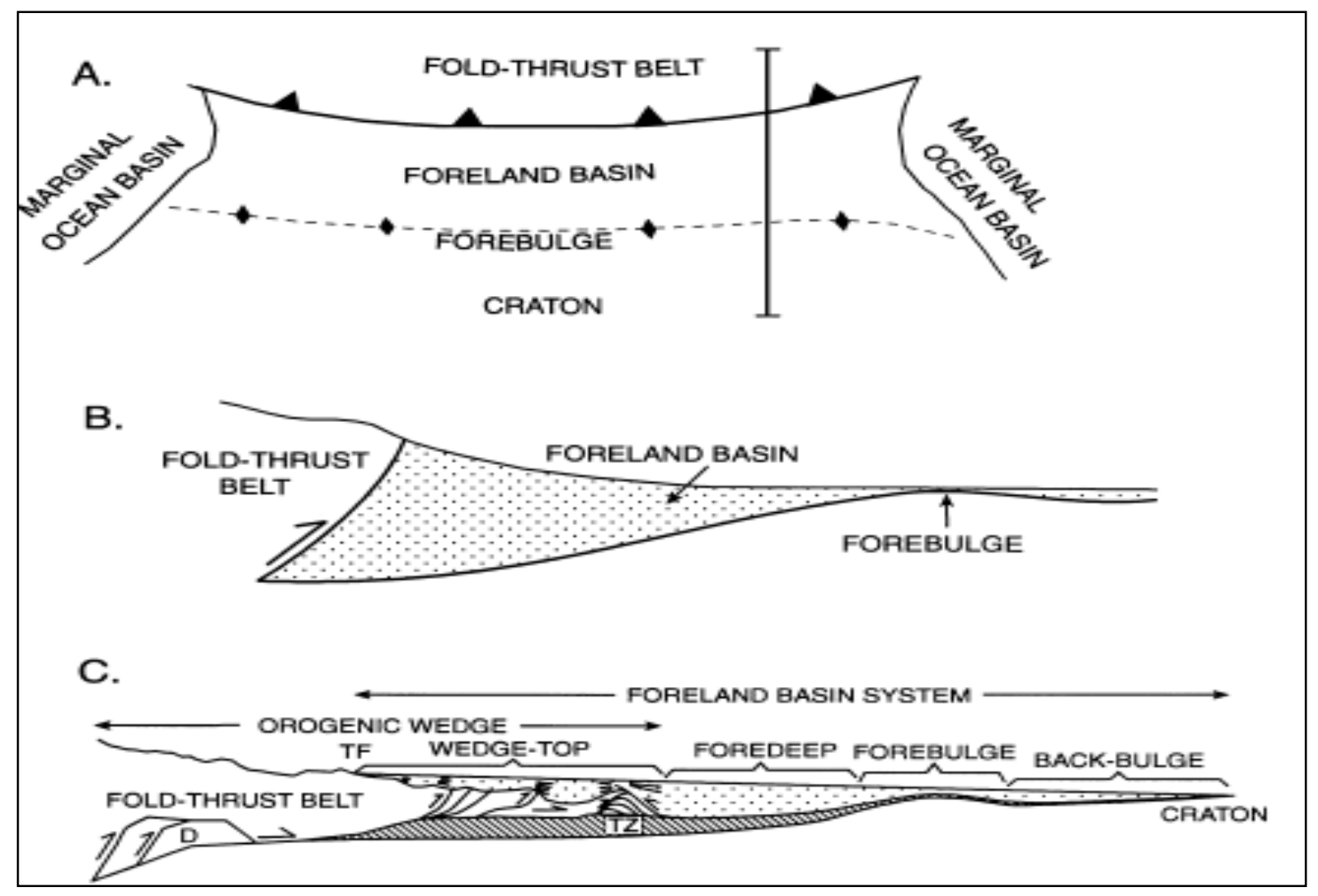

Fig. 2. A- Schematic map of a typical Foreland basin, B- Cross-section showing the wedge shape of the Foreland basin, C-Cross section showing units of the Foreland basin system (DeCelles and Giles 1996)

III. The longitudinal span of the foreland basin system is approximately equal to the length of the adjacent thrust belt. The main mechanisms of continental crust disturbance in the Foreland basin systems are bending in response to orogenic loading and subsurface loads, but this bend may be revealed differently in each depozone, consequently, facies changes track the progressive evolution of the foreland-thrust wedge system (Sabbatino et al., 2020) (Fig. 3). 


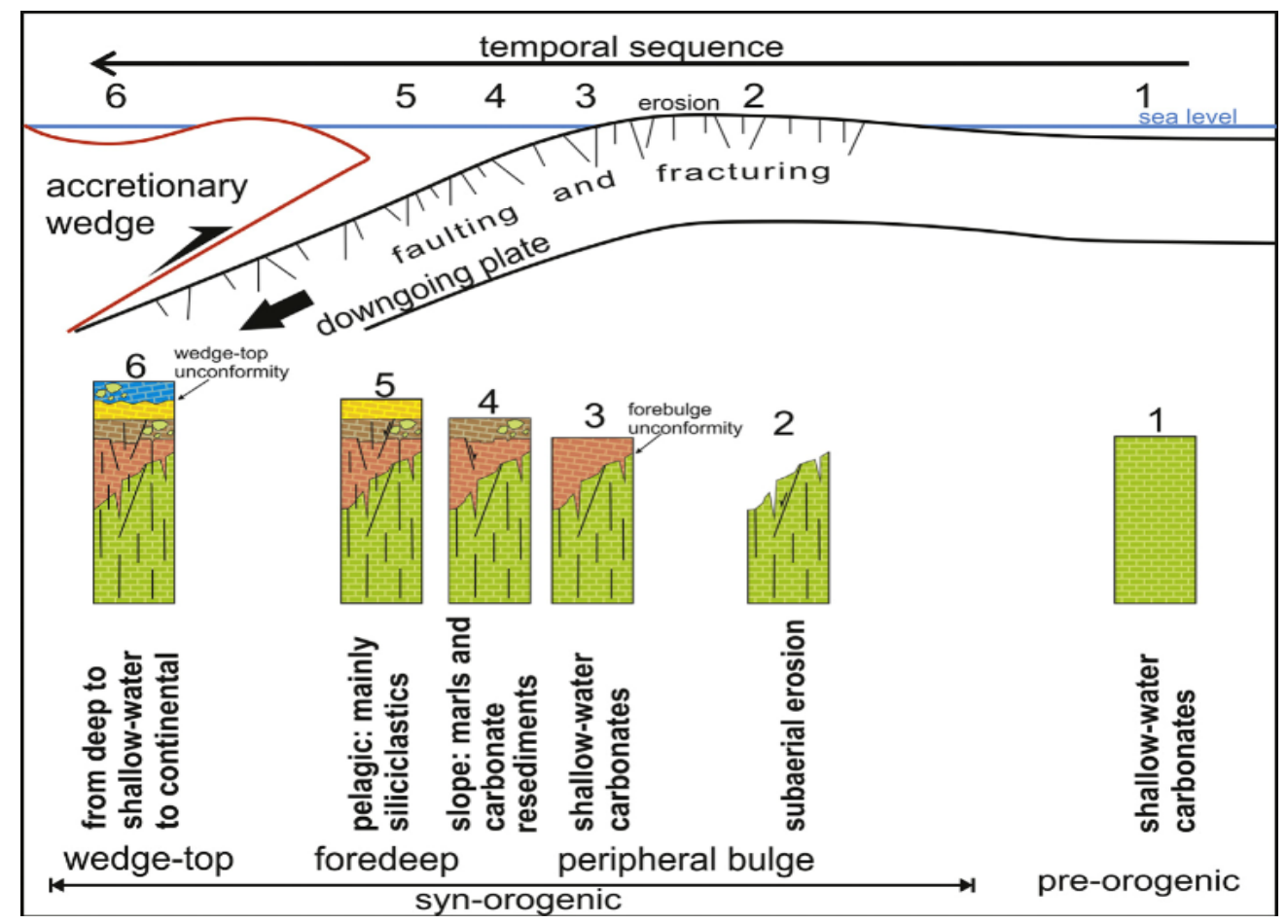

Fig. 3. Schematic tectonostratigraphic evolution of a foreland basin system in response to the accretionary wedge (tectonics load) migration (Sabbatino et al., 2020)

\section{Shiranish Formation}

The formation first described by (Henson, 1950 in Bellen et al., 1959), for which the type section identified nearby the village of Shiranish Islam north Zakho town in northern Iraq, but the coordinates installed in the above-mentioned references N 37 $11^{\prime} 32^{\prime \prime}$ and E 42 $50^{\prime} 30^{\prime \prime}$. Do not coincide with the ground facts (Fig. 4). Therefore, the type section coordinates must correct to $\mathrm{N} 37^{\circ} 13^{\prime} 42.17^{\prime}$ and $\mathrm{E} 42^{\circ} 51^{\prime} 44.82$.

The thickness of the formation in the type section is 227.8 meters, consisting of blue marl in its upper part and a thickness of 99 meters, while the bottom part is 128.8 meters consists of marly limestone rich in fossils, of a light blue color (or dark or black in the case of organic materials). The age of the formation is the upper Campanian-Maastrichtian (Bellen et al., 1959). Shiranish Formation in the type section is above the Bekhme Formation and it is located below the Kolosh Formation as in (Fig. 5). Shiranish Formation is equivalent to part of Kermave series in Southeast Turkey (Bellen et al., 1959). In addition, it is equivalent to the upper part of the pelagic Gurpi Formation in the northwest and southwest Iran (Jassim and Buday, 2006). In the Dukan area, Shiranish Formation is setting disconformable above the Turonian Kometan Formation (Abdel-Kareem, 1983; Jaff, 2015). While (Karim et al., 2008) 
considered conformable contact but they were not excluded short submarine erosions and slow rate of sedimentation across the contact.

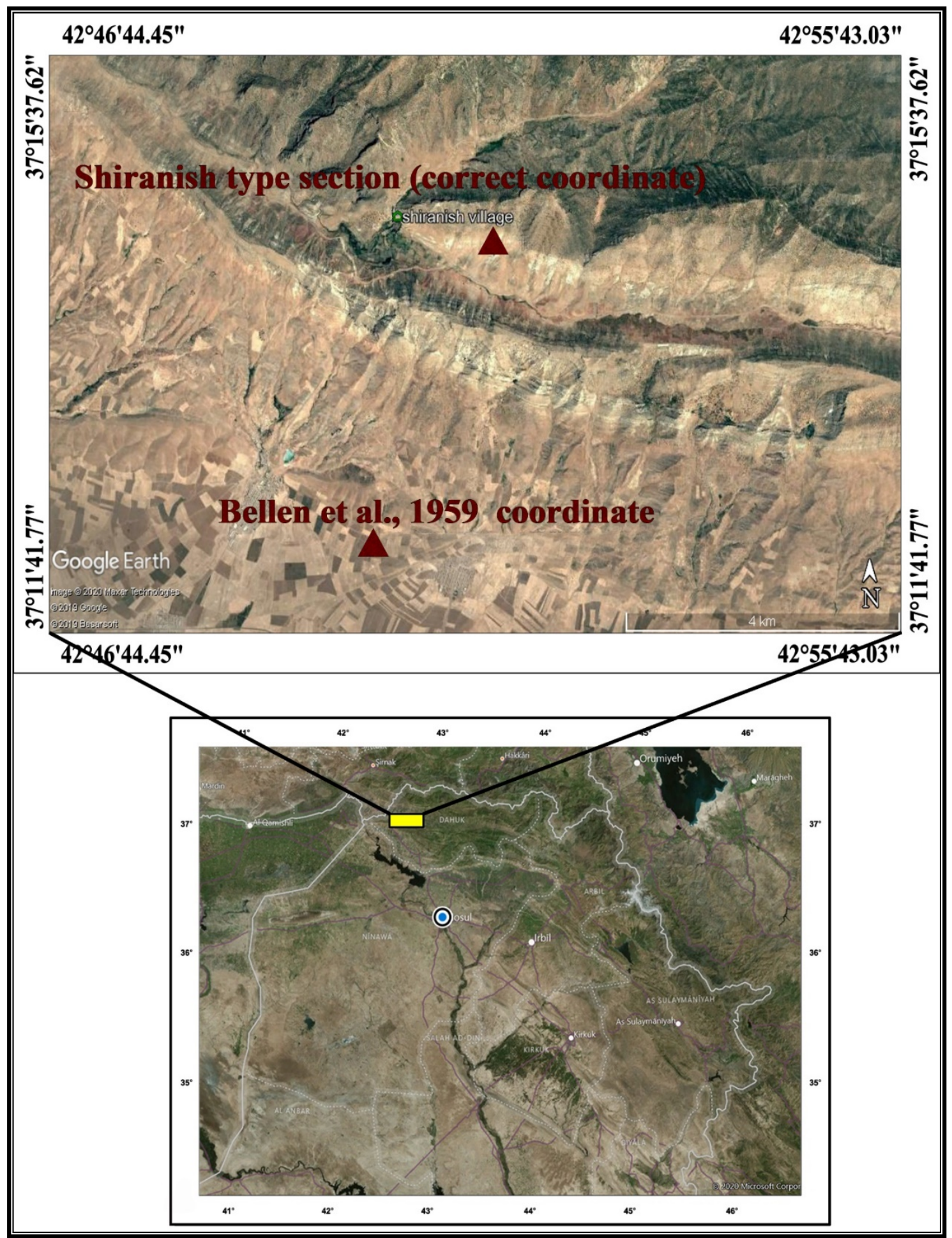

Fig. 4. The difference between location of the Shiranish Formation and coordinates mentioned in (Bellen et al., 1959) for the type section in Shiranish area

In the Hijran area near Shaqlawa, the formation lies disconformably on the Upper Qamchuqa Formation (Yahya and Al-Shammary, 1993). The variability in the thickness of 
the Shiranish Formation may be related to the conditions of subsidence during deposition and the degree of post-Cretaceous denudation and the replacement of the formation by other synchronous sedimentary units mainly by the Tanjero and Aqra-Bekhme formations (Buday, 1980). The thickness of the Shiranish Formation reaches $1300 \mathrm{~m}$ between Hemrin and Mandali-Diyala province (Homci, 1975 in Jassim and Budy 2006). The thickness decreases towards the west of Iraq, reaching $50 \mathrm{~m}$ on the western rim of the Ga'aara depression (Jassim and Budy, 2006).

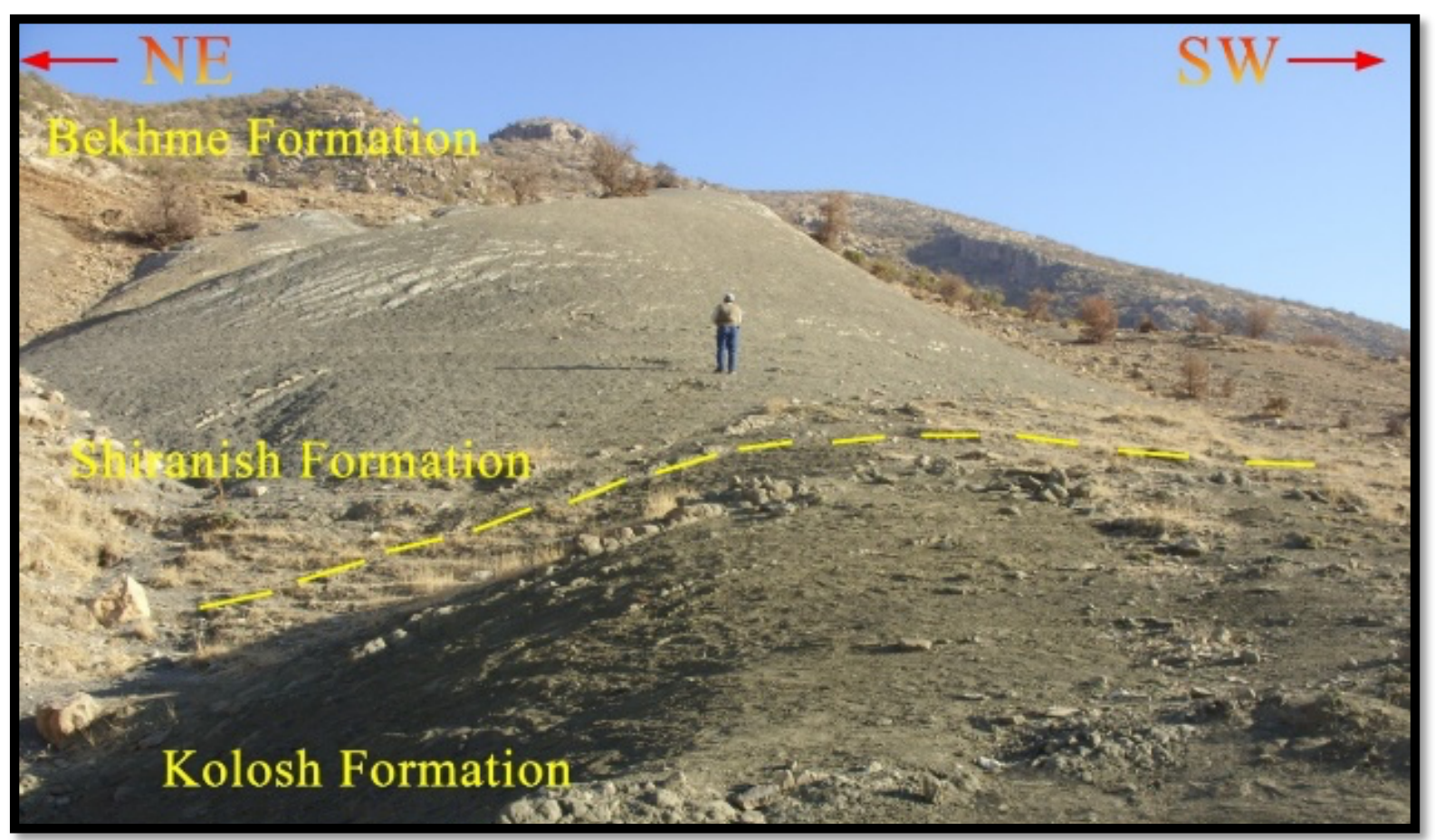

Fig. 5. The contact boundary between the Shiranish and the Kolosh formations in the type section Zakho region

RESULTS

\section{Tectonic Model of Underfill Stage of Iraqi Zagros Foreland Basin}

The climax of the ophiolite obduction over the Afro-Arabian plate and raised above sea level occurred through Late Campanian and Maastrichtian (Jassim and Goff, 2006; Alavi, 2007) or accumulation of accretionary prism of Qulqula Radiolarite serpentinite mélange slices according to (Ali et al., 2019; Aziz et al., 2011a).

Around the same time, the characteristics of the foreland basin system were manifested, where the accretionary prism and ophiolite thrust slices formed the top-wedge of depozone. Synchronize with the sedimentation of the typical three lithostratigraphic units that named underfilled trinity units by (Sinclair, 1997a) in the foredeep depozone, which are diachronous and generally superimposed on top of one another during craton ward movement of the facies belts. The lower unit (Fig. 6A), comprises of shallow marine limestone (Bekhme Formation) 
that termed the synorogenic carbonate platform by (Znad, 2013), underlain by an unconformity with Qamchuqa Formation (Bellen et al., 1959). The middle unit comprises of pelagic and semi pelagic sediments (Shiranish Formation). The upper unit comprises of flysch sediments (Tanjero Formation) derived from an orogenic wedge. The basinal situation of the underfilled trinity in a foredeep depozone of the foreland basin system, affected as the tectonic load thrusts above the craton, thus the foreland basin depozone migrates at about the same rate (Sinclair, 1997a). This results in a superposition of the three units of the trinity, as illustrated in (Fig. 6B). The basal unconformity consequences from elevating and erosion of the pre -foreland basin platform Region during flexural of the forebulge. (Fig. 6C). Chronostratigraphic demonstration of underfilled trinity shown in (Fig. 5B). Altogether three units are diachronous in response to the shifting of the basin axis. The middle unit reveals sedimentation offshore from the craton ward edge of the basin. The inception of the middle unit records the time when sea-level upraise accompanying with flexural subsidence overcome the growth of water carbonate platforms (Dorobek, 1995).

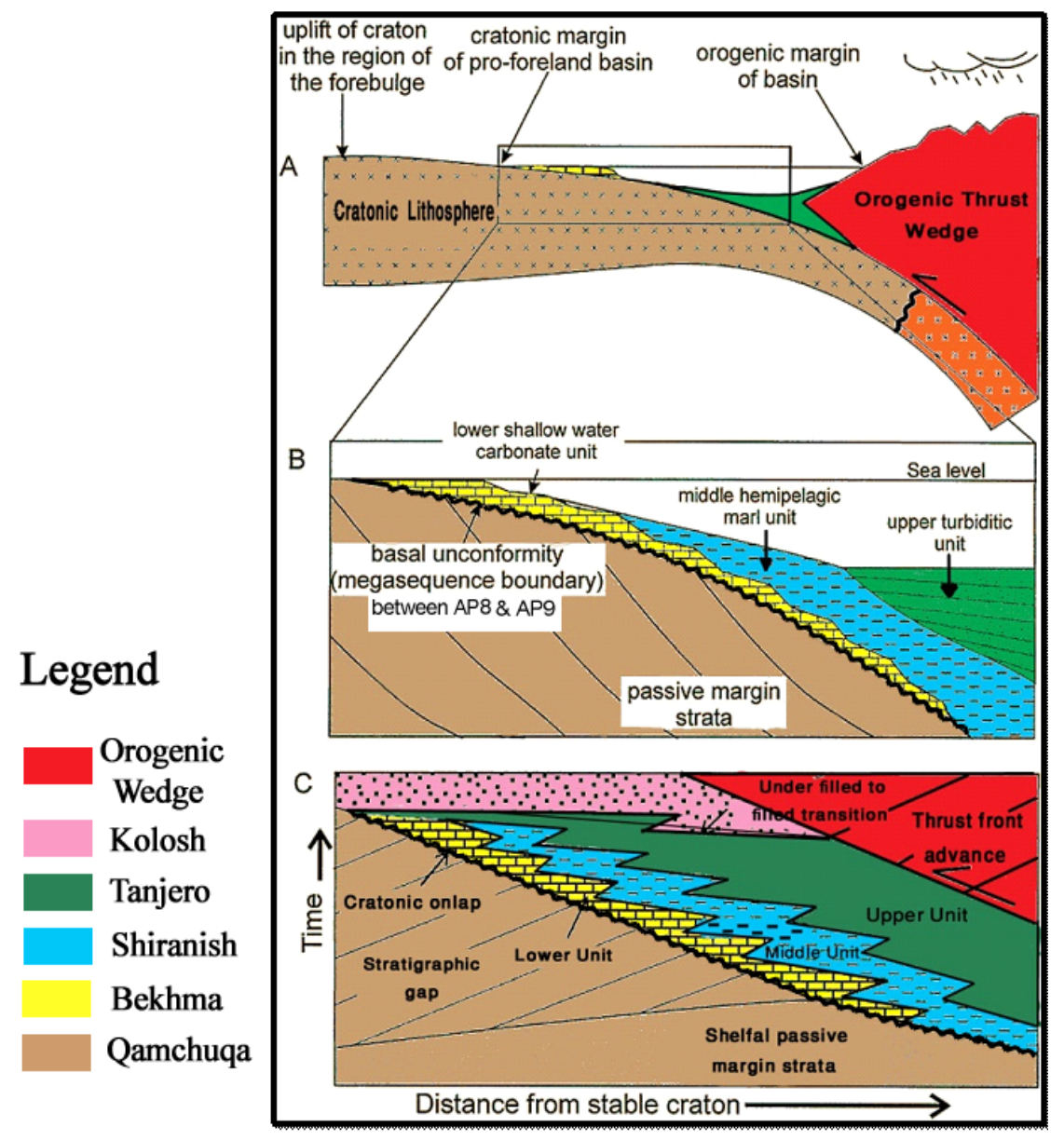

Fig. 6. Trinity underfill model of Zagros foredeep depozone, modified from (Sinclair, 1997a) 
These lithostratigraphic units are separated from underling by unconformity resulted from erosion over a forebulge (Qamchuqa Formation) (Fig. 7). That represented a mega sequence boundary between AP8-Late Jurassic to Late Cretaceous, and AP9-Late Cretaceous to Early Palaeogene (Sharland et al., 2001) and termed by (Znad, 2013) forebulge unconformity in northern Iraq.

\section{Isopach Map of the Shiranish Formation and Tectonic Interpretation}

Isopach maps represent a valuable tool to outline the tectonic framework of sedimentary basin and the structural relationship responsible for accumulation a specific type of sediment (Krumbein and Sloss, 1963). Practically, thickness maps also are valuable to explicate major depositional center locations and borders and as depositional synchronous subsurface structural relieves where sediments become thinner and shallower (Miall, 1999). Detailed surface observations and field data are the basis for mapping, as well as subsurface information obtained from the records of some exploratory wells. The map, (Fig. 8), has drawn using (Surfer V.13) software. The map pronounces the occurrence of the Shiranish Formation sediments according to foreland basin system depozones as follow: -

In foredeep depozone the formation spread within the Sulaymaniyah district and extending northwest in the direction of Soran, Rawondoze, Barzan area. This depozone in the Iraqi segment represents the extent of Southeast Turkey and Northwest in Iran of major Zagros foreland system. Tectonic behavior of forebulge depozone (Qamchuqa Formation) in the late Campanian-Maastrichtian has regulated deposits of the Shiranish sediments, since the absence of the Shiranish Formation on northern and southern limbs of both Mateen and Gara anticlines, and ahead to Aqra anticline, suggesting forebulge was shallow under immersion, creating conditions for the growth of Aqra Formation.

It seems the forebulge, starting to drown from the area between Gali Zanta and Gali Bekhme, through the gradational variation of the lower part of the Aqra Formation to the upper Shiranish Formation (Karim et al., 2012). With understanding the Aqra Formation had been deposited unconformably above the forebulge (Qamchuqa Formation), accordingly, the Shiranish Formation begins to appear clearly from the Bijil area and extended into Shaqlawa, Taqtaq, and Kirkuk toward southeast into Iran. The variation of the Aqra Formation to the Shiranish Formation also recorded by (Chatton and Hart, 1961) (Fig. 9). In the" backbulge depozone" through NE-SW Geological Cross Section including Mosul and Aqra area. 


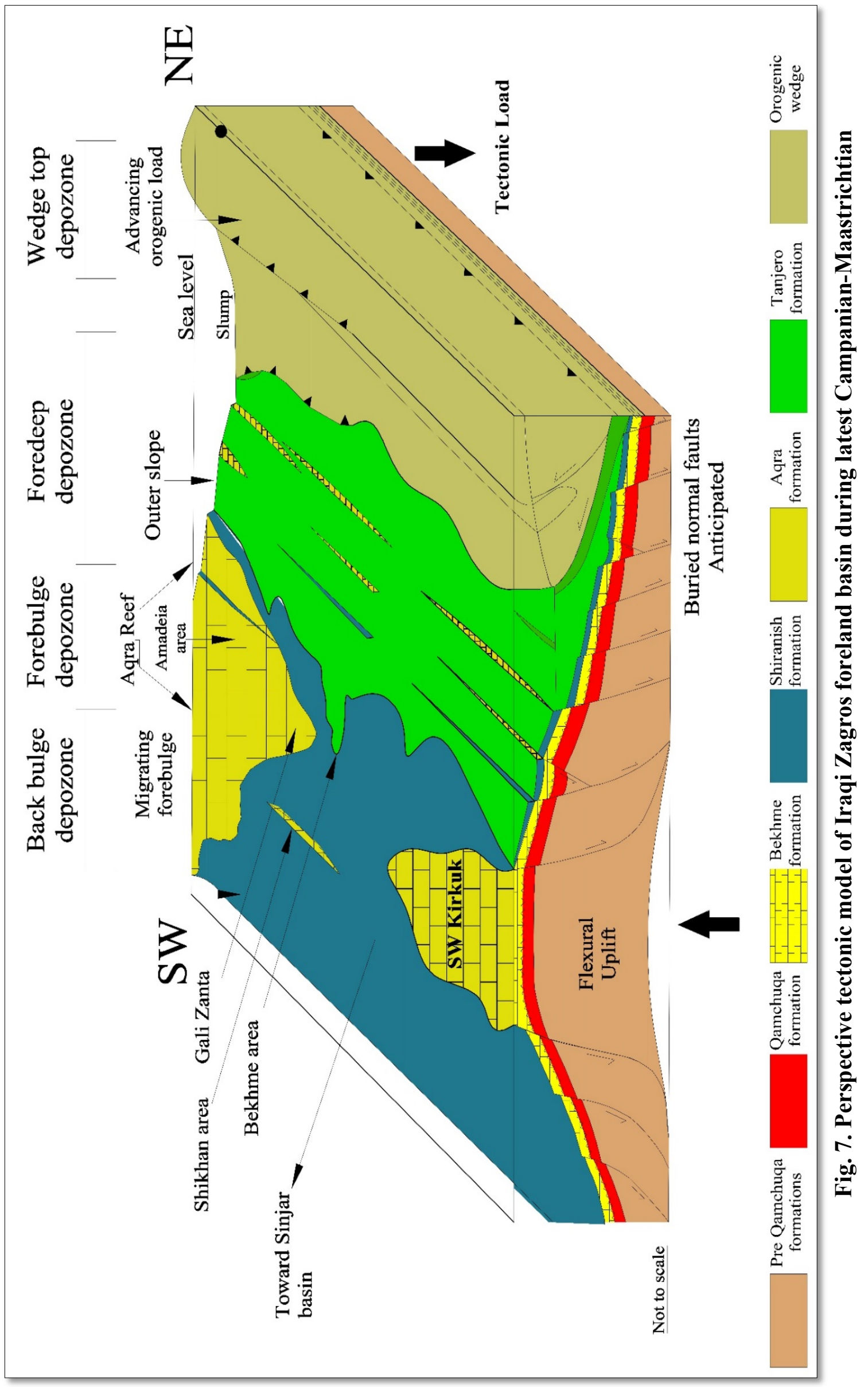




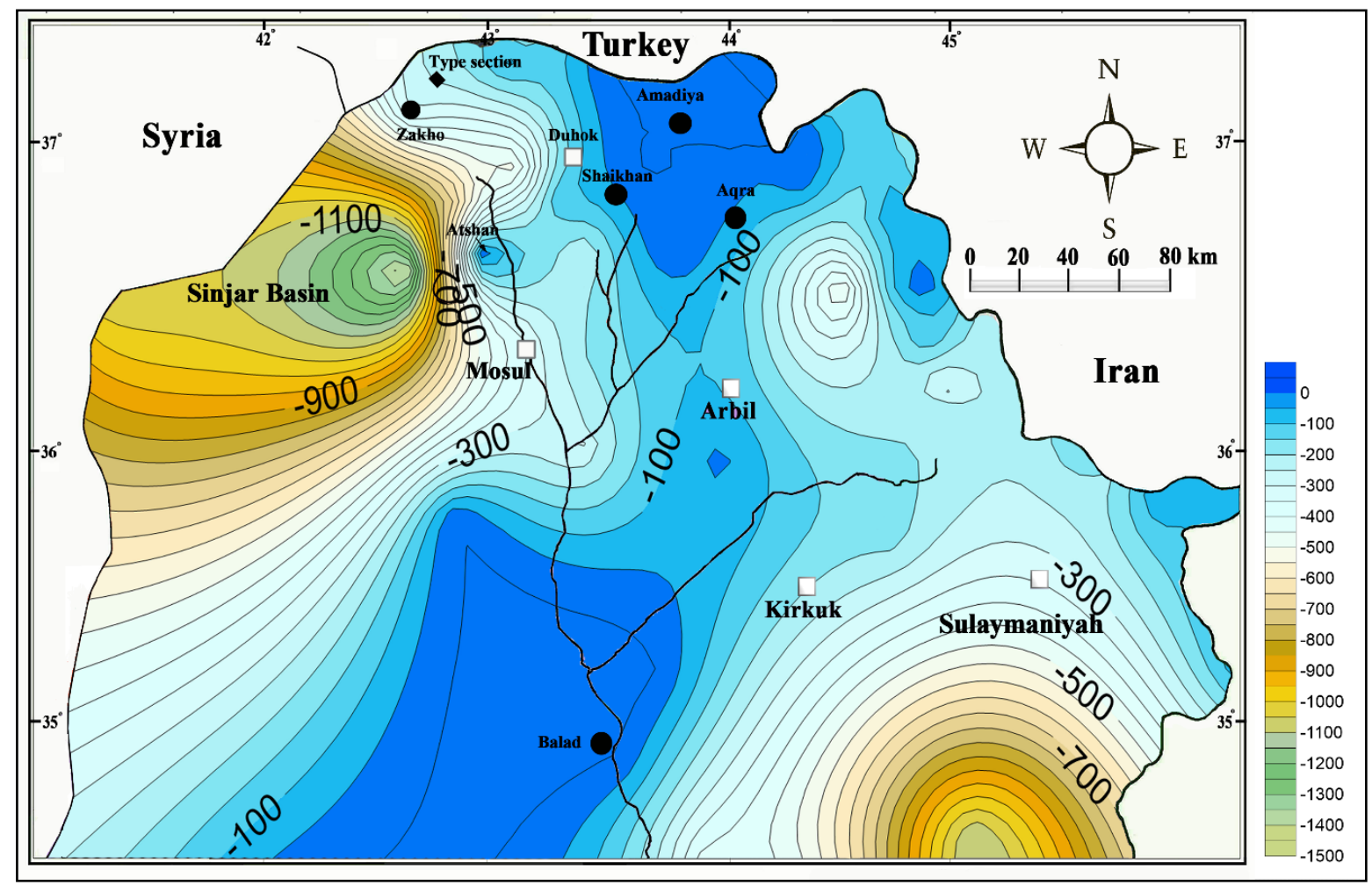

Fig. 8. Isopach map of the Shiranish Formation in the foreland basin northern Iraq

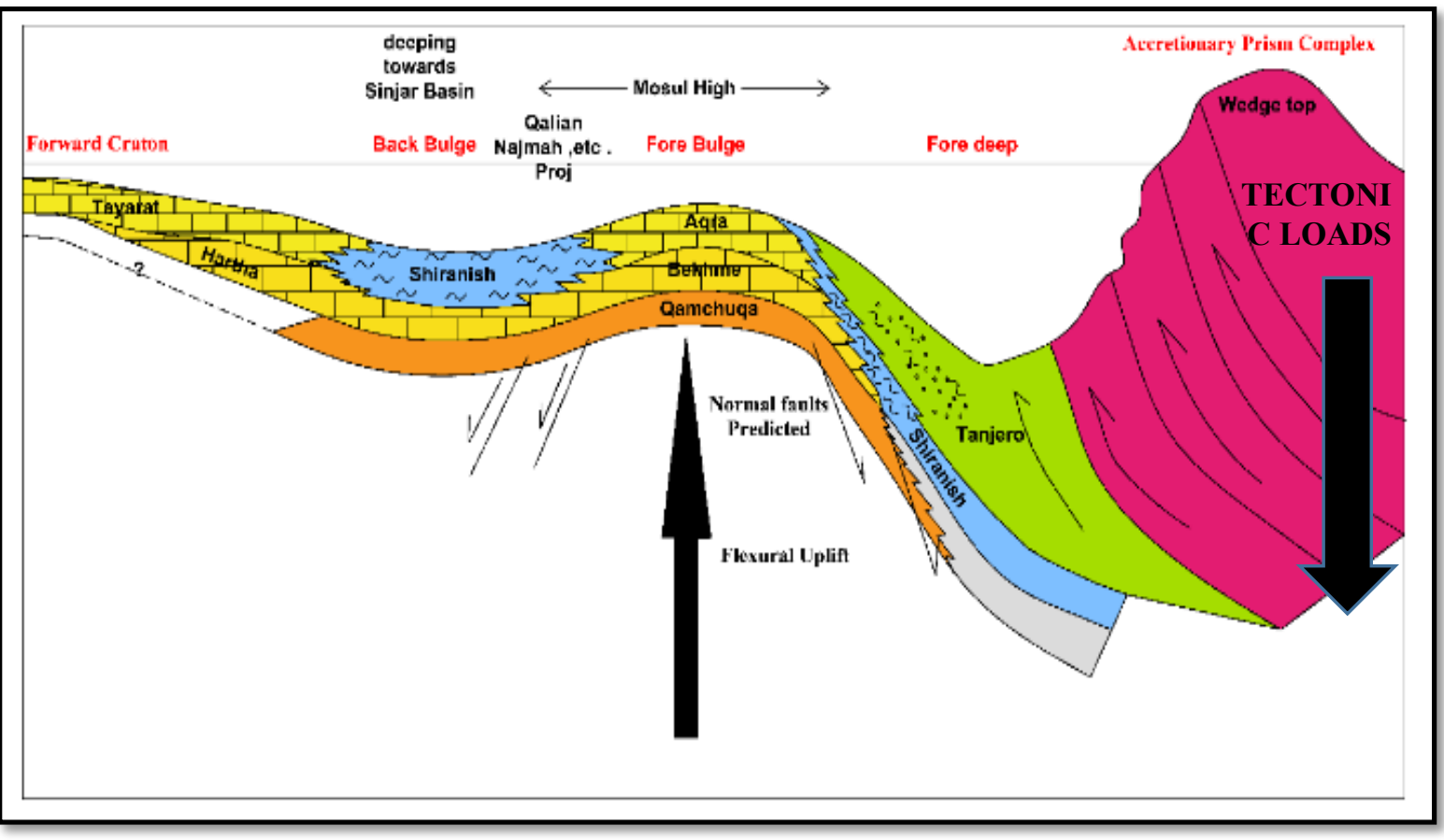

Fig. 9. NE-SW cross section illustrates the Late Cretaceous succession with depozone of foreland basin system, modified from (Chatton and Hart, 1961)

the forebulge commenced to plunge towards the southeast, starting from Bekhme area (specifically near the northwest plunge of the Berat anticline), and began the deposition of the Shiranish Formation toward Shaqlawa, Taqtq and Kirkuk and continue to the southeast. The 
map shows its emergence of forebulge again west of the Tigris River and in Al-Thathar depression direction, as the Shiranish Formation was not recorded in the exploration wells and then the forebulge sinking towards central and southern Iraq. The forebulge protrusion did not appear to be homogeneous along its length, form NW to $\mathrm{S}$ as it suffered from subsidence similar to (Antiformal Depression) as shown in Fig. 10.

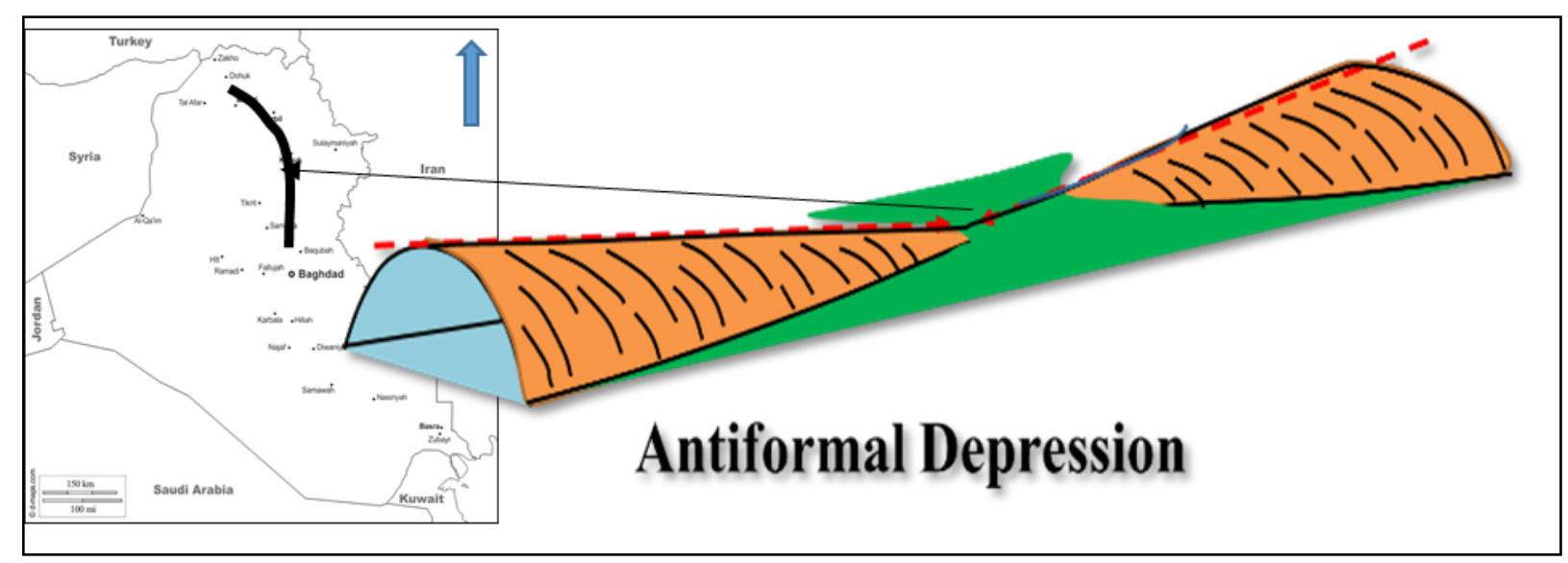

Fig. 10. Antiformal depression like of forebulge

In the area southwest of the Kirkuk towards Gayara and westward the Shiranish Formation deposited in this depression. The map shows a major sedimentation center in the back-bulge depozone. This deposition center (Sinjar basin) extends towards (east -west). Sinjar basin was a small sedimentary basin west of the Mosul city where it reached the highest formation thickness during Mesozoic that inverted in Neogene (Sawaf et al., 1993). The map shows that this basin starts from the Baikher Anticline and extends towards the center of the basin as well as it starts from southeast of the Mosul city towards the center of the basin as well. This basin may represent a tectonic depression (Graben), inherited from the rifting of Gondwana plate. The rifting, however, took place of the continental margin of AfroNubian_plate during the early Mesozoic (Numan, 1997).

The litho and biostratigraphic studies of the Shiranish Formation in the Sinjar basin show different lithological characteristics including limestone breccia and conglomeratic limestone, recorded within this formation (Al-Mutwali and Al-Jubori, 2005; Bellen et al., 1959). The Sinjar basin is referred to as in this study as "back-bulge depozone". The litho and biostratigraphy also have been noticed in Syria (the Jabal Abd El Aziz) (Ismail, 2011). These studies clearly support the subsidence tectonic activity (local extension setting) during the deposition of the formation. In Syria, the environment of deposition is referred by (Brew et al., 2001) as syn-extensional tectonic environment. The isopach contour map in the back bulge depozone shows a local closure around a thick central area, however, this outline 
indicating that there was an ongoing drop in the accommodation space for this depozone during the sedimentation (De Celles and Gelis, 1996).

Also, in the Mergasor area "foredeep depozone" records the change of facies to deeping upward cycle (Abdulah et al., 2018). Variations of sedimentary sequences may be attributed to subsidence which was caused by prolonged flexural due to the pulse of advancing tectonic loads during convergent phases and its impact as local extension environment in the structures of the foreland basin depozones (Sabbatino et al., 2020) (foredeep and backbulge depozones).It is important to note that the supracrustal loading by orogens leads to the subdividing of foreland systems into flexural depozones, the foredeep, forebulge, and backbulge (Fig.9). The upper Cretaceous Sinjar Basin likely established in the back-bulge depozone. This back-bulge basin (Fig.9) lays the craton ward of the forebulge, and contains marine carbonate deposition and siliciclastic sediment derived from the forebulge (Aqra and Bekhme formations) as well as the craton-derived sedimentary rocks (Hartha and Tayarat formations) further to the west. Litho and biostratigraphic study of the Shiranish Formation of Sinjar Basin supported that the subsidence was caused by tectonic activity due to advancing propagation of the orogenic wedge and regional flexural subsidence under this tectonic load.

The map shows the presence of a sedimentary basin in the area of Balad and Samarra, it indicates that it locates within the foredeep depozone basin, which extends from Taqtq passing through Kirkuk and towards central Iraq. The map shows a slight rise in the center of Iraq and then continue the deposition of the Formation to change gradually to the Hartha Formation.

\section{CONCLUSIONS}

The deposition of the syn-extensional Shiranish Formation, which represents the middle unit of the trinity underfilled lithofacies stage of Iraq Zagros foreland basin, that have been affected by the tectonics of the Foreland basin and its depozones. Although the formation was deposited during the compressive phase (convergent plates) during closer of Neo-Tethys, it is deposited in an extension environment both in the foredeep and in the backbulge, where the deposition of the formation in the basin of the foredeep and absence on the forebulge depozone in the area of Amadia extending to Aqra and Sheikhan. At the same time, there was a deposit in a backbulge depozone in the areas of Baikher and Kali Dehi at the western plunge of Matin and Garah anticlines. That was the eastern edge of the descending basin of Sinjar Abd el Aziz westward direction. Intraformational limestone conglomerate occurrence in the formation NW Iraq, Sinjar area, and in Syria in the Abdul Aziz anticline was probably 
resulting from collapses due to tectonic pulses associated with convergent plates phases Also, the change of facies to Deeping upward cycle in the foredeep depozone Indication deposition in subsidence basins.

\section{REFERENCES}

Abdel-Kireem, M. R., 1983. A study of the paleoecology and bathymetry of the foraminiferal assemblages of the Shiranish Formation (Upper Cretaceous), northeastern Iraq. Paleogeography, Paleoclimatology, Paleoecology, 43 (1-2):169-180.

Abdula, R. A., Saradr, B.Y., and Mumad, M., 2018. Sedimentology of the Shiranish Formation in the Mergasur area, Iraqi Kurdistan. Bulletin of the Geological Society of Malaysia, 65: $37-43$.

Agard, P.J., Omrani, L. J., olivet, H., Whitechurch, B., Vrielynck, W., Spakma,P., Monié, B., Meyer and Worte, 2011. Zagros orogeny: A subduction-dominated process. Geological Magazine, 148 (5-6): 692-725.

Alavi, M., 2007. Structures of the Zagros fold-thrust belt in Iran. American Journal of Science, 307:1064 -1095.

Allen, P. A., and Allen, J. R., 2005. Basin Analysis - Principles and Applications, 2nd edition. Blackwell Publishing, Malden, 549 P.

Al-Mutwali, M. M., and Al-Juboury, F. N., 2005. Litho and biostratigraphy of the Shiranish Formation (Late Campanian-Late Maastrichtian) in Sinjar Area, Northwestern Iraq.: Rafidain Journal Science, 16 (1): 152-176.

Alsharhan, A. S., and Nairen, A. E. M., 2003. Sedimentary Basins and Petroleum Geology of the Middle East. Elsevier, PP. 575-597.

Ali, S. A., Nutmana, A. P., Aswad, K. J., and Jonesa, B. G., 2019. Overview of the tectonic evolution of the Iraqi Zagros thrust zone: Sixty million years of Neotethyan ocean subduction. Journal of Geodynamics. 129:162-177.

Aziz, N. R. H., Aswad, K. J. and Koyi, H. A., 2011a. Contrasting settings of serpentinite bodies in the northwestern Zagros suture zone, Kurdistan Region. Iraqi Geological Magazine,148 :819-837.

Beaumont, C., 1981. Foreland basins: Geophysical Journal of the Royal Astronomical Society, 65:291-329.

Bellen, V. R. C., Dunnington, H. V., Wetzel, R. and Morton, D. M., 1959. Lexique Stratigraphique International. Fasc.10a, Iraq, Paris, 333p.

Brew, G., and Barazangi, M., 2001. Tectonic and geologic evolution of Syria. GeoArabia, 6 (4):573-613.

Catuneanu, O., 2004. Basement control on flexural profiles and the distribution of Foreland facies: The Dwyka group of the Karoo Basin, South Africa. Geology, 32 (6): 517-520.

Chatton, M. and Hart, E., 1961. Review of the Cenomanian to Maastrichtian stratigraphy in Iraq. Manuscript Report No.2/141.80p. INOC Library. Baghdad.

Buday, T.,1980. The Regional Geology of Iraq.Vol.1: Stratigraphy and Paleogeography. Geosurv Publication, Baghdad 445P.

De Celles, P. G., and Giles, K. A., 1996. Foreland basin systems: Basin Research, 8:105-125.

De Celles, P.G., 2012. Foreland Basin Systems Revisited: Variations in Response to Tectonic Settings. Tectonics of Sedimentary Basins: Recent Advances, First Edition. Edited by Cathy Busby and Antonio Azor Pe'rez. Blackwell Publishing. Chapter 20. 22 P.

Dorobek, S. M., 1995. Synorogenic Carbonate Platforms and Reefs in Foreland Basins: Controls on stratigraphic Evolution and platform/reef morphology In Stratigraphic evolution of foreland basins (Eds. S.M. Dorobek, and G. Ross), SEPM Spec. Publ., 52, Tulsa, pp. 127-146.

Homke, S., 2007. Timing of Shortening and Uplift of the Pusht-E Kuh Arc in the Zagros Fold-and- Thrust Belt (Iran) .A Combined Magneto stratigraphy Apatite Thermochronology Analysis. Ph.D. Thesis, Universitat de Barcelona Facultat de Geologia Department de Geodinàmica i Geofísica.

Ibrahim, A. O., 2009. Tectonic style and evolution of the NW segment of the Zagros Fold - Thrust Belt, Sulaimani Governorate, Kurdistan region NE Iraq. Unpub. Ph.D. thesis, University of Sulaimani, Kurdistan region, Iraq, $200 \mathrm{pp}$.

Ismail, S., 2011. Sedimentology and Petroleum Potential of the Late Cretaceous Shiranish Formation in the Euphrates Graben, Syria. Unpub. Ph.D. thesis, University of Berlin University- Germany.267P. 
Jaff, R. B. N., 2015. Late Cretaceous Foraminifera from the Kurdistan Region, Ne Iraq: Paleontological Biostratigraphical and Paleoenvironmental Significance. Unpub. Ph.D. Thesis, University of Leicester. 282P.

Jassim, S. Z., and Buday, T., 2006b. Tectonic Frame work. In: Jassim, S.Z. and Goff, T (eds.), Geology of Iraq. Publication of Dolin, Prague and Moravian Museum, Brno, 341p.

Jassim, S. Z., and Buday, T., 2006. Late Turonian-Danian Megasequence AP9. In: Jassim, S.Z. and Goff, T (eds.), Geology of Iraq. Publication of Dolin, Prague and Moravian Museum, Brno, 341p.

Jassim, S. Z., and Goff, J. C., 2006. Phanerozoic development of the Northern Arabian Plate. (Chapter 3) Regional Geology of Iraq. Dolin, Prague and Moravian Museum, Brno, Czech Republic, 341 p .

Karim, K. H., Ismail, K. M., and Ameen, B. M., 2008. Lithostratigraphic study of the contact between Kometan and Shiranish formations (Cretaceous) from Sulaymaniyah Governorate, Kurdistan Region. Iraqi Bulletin of Geology and Mining, 4(2):16-27.

Karim, K. H., Znad, R. K., and Sirwan, H. A., 2012. Relations between deep and shallow stratigraphic units of Northern Iraq during Cretaceous. Iranian Journal of Earth Sciences, 4:95-103

Krumbein, W. C., and Sloss, L. L., 1963. Stratigraphy and Sedimentation. W.H. Freeman and Co; 2nd Edition, $660 \mathrm{p}$.

Miall, A. D., 1999. Principles of sedimentary basin analysis. Springer -3rd. updated and enlarged edition.634P.

Naylor, M. and Sinclair, H. D., 2008. Pro vs. Retro foreland basins. Basin Research, 20:119. doi:10.1111/j.13652117.2008.00366.

Numan, N. M. S., 1997. A plate tectonic scenario for the Phanerozoic succession in Iraq, Geological Society Iraqi Journal, 30 (2): 85-110.

Sabbatino, M., Vitale, S., Tavani, S., Consorti, L., Corradetti, A., Cipriani, A., Arienzo, I. and Parente, M., 2020. Constraining the onset of flexural subsidence and peripheral bulge extension in the Miocene foreland of the southern Apennines (Italy) by Sr-isotope stratigraphy. Sedimentary Geology Volume 401.

Sawaf, T., Al-Saad, D., Gebran, A., Barazangi, M., Best, J. and Chaimove, T., 1993 .Stratigraphy and structure of Eastern Syria across the Euphrates depression, Tectonophysics, 220: 267-281.

Sharland, P. R., Archer, R., Casey, D. M., Davis, R.B., Hall, S. H., Heward, A. P., Horbury, A. D. and Simmons, M. D., 2001. Arabian plate sequence stratigraphy. GeoArabia. Bahrain, special publication 2: Bahrain,371P.

Sinclair, H. D., 1997a. Tectonostratigraphic model of underfilled peripheral foreland basins: An Alpine perspective: Geological Society of America Bulletin, 109: 323-346.

Yahya, V. A., and Al-Shammary, T. A., 1993. Sedimentary features and processes in the Shiranish and Tanjero formations, Shaqlawa Area, Erbil, North Iraq. Iraqi Geological Journal, 26(3):135-154.

Znad, R. K., 2013. Early Cretaceous - Early Eocene Tectonic Evolution of a Part of Zagros Foreland Basin, Northern Iraq. Unpub. Ph.D. Thesis, Mosul University, 194p. (In Arabic) 